\title{
Yak Domestication: A Review of Linguistic, Archaeological, and Genetic Evidence
}

\author{
Guillaume Jacques $^{1 *}$, Jade d'Alpoim Guedes ${ }^{2}$, and Zhang Shuya ${ }^{3}$ \\ ${ }^{1}$ French National Centre for Scientific Research, Paris, France. ${ }^{2}$ Department of Anthropology, University of California, San \\ Diego, USA. ${ }^{3}$ ILCAA, Tokyo University of Foreign Studies, Tokyo, Japan. \\ *rgyalrongskad@gmail.com
}

\begin{abstract}
Yak, a species of bovid uniquely adapted to high-altitude environments, plays a critical role in the life of the inhabitants of the Tibetan Plateau and neighboring areas. There is currently no consensus on when these animals may have been domesticated. In this paper, we review the archaeological, genetic, and linguistic evidence relevant to this question, and suggest that the domestication took place following hybridization with taurine cattle from the end of the fourth millennium BCE. This study also shows that the original domesticators of yaks included not only the ancestors of the Tibetans, but also Rgyalrongic speaking people from Eastern Tibet.

Received March 4, 2021

OPEN OACCESS

Accepted June 21, 2021

Published October 13, 2021

DOI 10.14237/ebl.12.1.2021.1755

Keywords Yak, Domestication, Tibet, Taurine cattle, Linguistics, Archaeology

Copyright (c) 2021 by the author(s); licensee Society of Ethnobiology. This is an open-access article distributed under the terms of the Creative Commons Attribution-NonCommercial 4.0 International Public License (https://creativecommons.org/licenses/by-nc/4.0), which permits non-commercial use, distribution, and reproduction in any medium, provided the original author and source are credited.
\end{abstract}

\section{Introduction}

Yaks (Bos grunniens) provide important resources for millions of Tibetans, not just in the form of meat, but also in the form of secondary products such as milk products, hide, and fur that can be spun into black tents that retain moisture when it rains and prevents the tent from leaking. Yak dung provides a vital fuel source (Rhode et al. 2007); it also serves as construction material in walls, enclosures, storage houses for frozen meat, dog houses, tethers to which dogs and yaks can be attached, and even for manufacturing toys. Yaks are frequently crossbred with domestic cattle, producing a F1 hybrid dzo, which are valued for their increased milk production, and ability to adapt to the lower altitudinal range for yaks (between 2500-3500 masl). Rhode et al. (2007) have argued that meeting fuel needs may have led to the integration of the yak into early foragers survival mechanisms on the Plateau and eventually its domestication.

Yaks have a set of traits that have allowed them to adapt to the high-altitude environment of the Plateau: a thick coat that keeps them warm in freezing winters, increased heart and lung size, and increased foraging ability through an adapted tongue that allows them to easily eat the low-lying forage grasses that characterize areas of the Plateau. They likely diverged from wild cattle 4.9 million years ago and adapted to the Plateau over the course of its uplift (Qiu et al. 2012). Recent genetic comparisons of the yak to cattle have found that yaks possess unique adaptations to the low oxygen conditions of the Plateau: they identified an expansion of protein domains associated with hypoxic stress and nutrition metabolism, both traits that were likely important over the course of its evolution on the Plateau (Qiu et al. 2012).

To date, there is only disparate archaeological evidence of when humans first began to manage and eventually domesticate this animal. Below, we review the archaeological, genetic, and linguistic evidence for yak domestication. Linguistic evidence reveals that languages which have the most elaborate terminology for yak are Tibetic and Rgyalrongic, suggesting that its domestication may have taken place somewhere among the speakers of the ancestors of these languages. The speakers of proto-Tibetic and proto- 
Rgyalrongic appear to have independently cross-bred yaks with cattle, and the breeding of F1 hybrids predates the proto-Rgyalrongic split (3221 [21694319] BP, according to Sagart et al. 2019), which implies that the inhabitants of the eastern Plateau had begun to experiment with cattle/yak hybridization.

\section{Geographic Background}

The domestic yak is present over a large area, spread over ten countries (Afghanistan, Bhutan, China, India, Kyrgyzstan, Mongolia, Nepal, Pakistan, Russia, and Tajikistan; Joshi et al. 2020) comprising a southern and a northern zone, linked in the west by the Pamir mountains, as shown in Figure 11.

The southern zone corresponds to the entire Tibetan Plateau from Qinghai and Sichuan in the East up to Baltistan in the West, including the southern slope of the Himalayas in India, Nepal, and Bhutan. This area reflects the maximal extent of the Tibetosphere, mainly inhabited by speakers of Tibetic languages (i.e., in direct descent from the language of the Tibetan empire, 618-842 CE; Tournadre and Suzuki 2021), but also speakers of Burushaski (a language isolate), Indo-Iranian (Indo-European), Turkic, Mongolic, and Sino-Tibetan languages that are culturally and linguistically influenced by Tibetan.

The non-Tibetic Sino-Tibetan languages of this zone mainly comprise either groups that are closely related to Tibetic, such as Tamangic, East Bodish (Hyslop 2013) and Bragsum (Tournadre and Suzuki 2021), languages of the Na-Qiangic branch, in particular Naic (Jacques and Michaud 2011), Ersuic (Yu 2012), Rgyalrongic (Sun 2000), as well as Muya, Zhaba and Queyu, and several isolated branches of the family including Tshangla (Bhutan), Kho-Bwa (Arunachal Pradesh, India) and Guiqiong (Sichuan, China).

The northern zone spreads from the Pamir mountains up to the Hangai mountains in Mongolia, north of the Taklamakan desert (Qi et al. 2008:429),

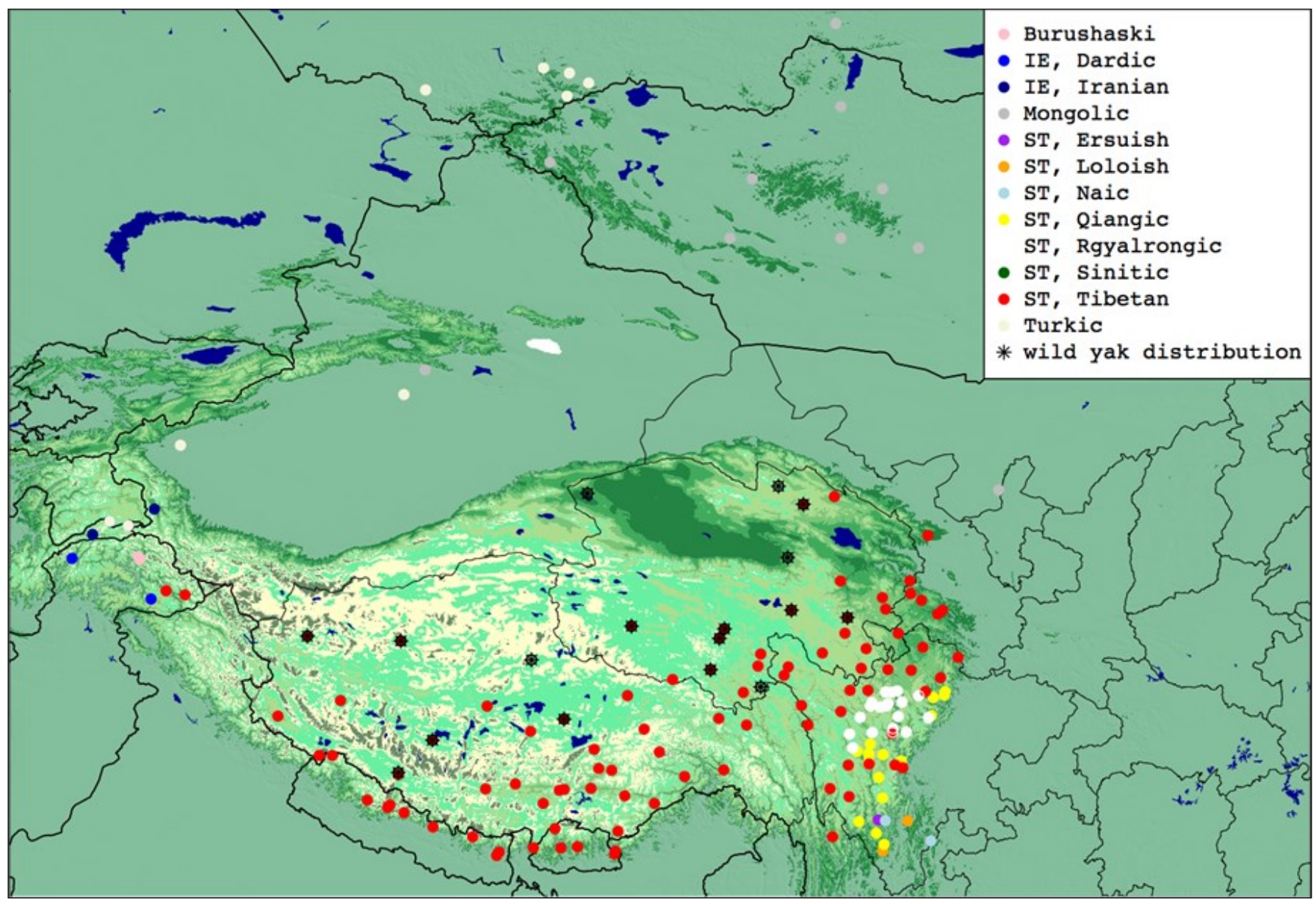

Figure 1 Geographic distribution of wild and domesticated yak. 
and is inhabited by speakers of Mongolic and some Turkic languages (Tyva, Altai).

Wild yaks (Bos mutus) are only restricted to a much smaller range, in several discontinuous refuge zones: the Chantang, Hoh Xil, Sanjiangyuan and Altun shan National Nature reserves, the Qilian mountains and an area in Ngari district in Tibetan autonomous region.

\section{Genetics and Archaeology}

Yaks belong to the Bovini tribe, a group of bovids, which have played an important role in human life: a source of milk, meat, hide for leather but also as draft animals where their muscle power was used for moving produce and ploughing fields. Several genera are important in understanding the history of domestication in Asia: the genus Bos which includes taurine cattle (Bos taurus taurus), Zebu (Bos taurus indicus), Yak (Bos grunniens), and domestic gaur (Bos frontalis). The genus Bubalus, which includes water buffalo (Bubalus arnee), were also important domesticates in Asia.

\section{Cattle}

Archaeological evidence suggests that taurine cattle were introduced to China from west Asia between 4500-2000 BP (Brunson et al. 2020; Cai et al. 2014; Flad et al. 2007; Lu et al. 2017). Ancient DNA analysis on mtDNA from 53 cattle remains between 45002300 years ago from across Northern China showed predominantly taurine cattle, an exotic introduction from the Near East (Cai et al. 2014), introduced at the same time as other Near Eastern species like wheat and barley.

Recent genetic work supports the two introductions of taurine cattle into East Asia that took place (Chen et al. 2018). Zooarchaeological evidence contains evidence for taurine cattle by roughly 5500 cal. BP in Gansu/Qinghai province, although more secure evidence dates to roughly 1000 years later (4500 cal. BP). Lu et al. (2017) point out, however, that the proportions of Bos taurus in earlier assemblages are very low and they do not appear to have formed an important component of the diet. On the Tibetan Plateau and its margins, bones of Bovids (Bos sp.) which may be Bos taurus, have been unearthed at Tawendaliha (3350-2750 cal. BP) and Talitaliha (3350-2750 cal. BP), Xiariyamakebu (3300 cal. BP; Dong et al. 2016), Ashaonao (2800-200 cal. BP; Kaoguxi et al. 2017).
Bos javanicus (banteng) and Bos frontalis (gayal) introgressed with both Zebu and taurine cattle in East Asia, providing cattle with adaptive traits to high temperatures. Likewise, yak was introgressed with taurine cattle on Tibet's margins, conferring adaptive traits to altitude (Chen et al. 2018).

\section{Archaeological Evidence for Yak Domestication}

Unfortunately, there is currently very little concrete evidence for yak domestication in the archaeological record. Physical evidence of yak skeletal remains has been found at Nuomohong sites on the northeastern Plateau, including Xiariyamakebu and Tawendaliha (3300-2700 BP), however, only their presence is noted, and it is unclear if they show signs of domestication (or what these signs of domestication might look like in yaks). At Talitaliha (3000-2700 BP), a clay sculpture of a yak demonstrates the importance this animal may have held for the inhabitants of the site (Qinghai Sheng Wenwu Guanli Huiyuanhui and Zhongguo Shehui Kexue Yuan Kaogu Yan-jiusuo Qinghai Dui 1963). At Qugong, a yak skull was also unearthed in an ashpit that dates to roughly $3650 \mathrm{BP}$ (Zhongguo Shehui Kexue Yuan Kaogu Yanjiusuo 1999). The authors argued that because of the relatively small size of the horns of the animal, it was likely domesticated (or hybridized with cattle). Yak skulls are also present in Samdzong 5 dating to 450 CE (Aldenderfer and Eng 2016).

Using pollen and charcoal analysis, some scholars have argued that humans may have modified yak's grazing lands via burning and encouraged the growth of grass and forbs on which these animals rely as early as 8000 BP (Huang et al. 2020; Miehe et al. 2009, 2014). This agrees with other sources on anthropogenic modification of the landscape as taking place by c. 5900 BP (Meyer et al. 2009; Schlütz and Lehmkuhl 2009).

\section{Genetic Evidence for Yak Domestication}

Genetic data has not been helpful in resolving this debate: some genetic papers predict a very early domestication (c. 10,000 BP; Guo et al. 2006), while other MtDNA data suggest that it took place twice roughly 5000 years ago (see discussion in Rhode et al. 2007; Bailey et al. 2002). Qiu et al. (2015) use molecular clocks to date yak domestication to roughly $7300 \mathrm{BP}$ and document a large increase in yak populations corresponding to $3600 \mathrm{BP}$ or the known spread of pastoral economies into the region. 
While there is no evidence for pastoralism as early as $7300 \mathrm{BP}$, it is possible that the encouragement of the growth of plant species on which yaks rely by foragers may have led to the population expansion and divergence in yak populations.

Following yak's domestication on the Tibetan Plateau, genetic evidence appears to support that it was then moved to Mongolia however it is unclear from the current data when this took place (Qi et al. 2010).

Bos taurus has been interbred with a number of other different species across Asia. A number of genetic studies have documented the introgression of taurine cattle genomes into yak populations and of yak genomes into taurine cattle on the Tibetan Plateau and in Mongolia (Chen et al. 2018; Medugorac et al. 2017; Qi et al. 2010). Medugorac et al. (2017) see an increase in the amount of introgression between yak and cattle populations taking place 1500 years ago with particular peaks around the Medieval Climate Anomaly (897-1121 CE) and the Dzungar-Qing Wars (1687-1758 CE).

Future genetic analysis on archaeological specimens may help us resolve the timing of the domestication of the yak.

\section{Linguistic Evidence}

Linguistics provide important evidence for the domestication of plants and animals. The study of systematic correspondences between related languages to reconstruct the vocabulary of their common ancestor (a field called Linguistic Paleontology) allows to constrain the range of hypotheses regarding the origin and way of life of the speakers of that proto-language (Hock 1991:573-578). It can be further applied to investigate the date of and place of domestication of plant and animal species (Brown et al. 2013).

This field of research uses the regular sound correspondences between cognate words in attested languages to reconstruct the proto-language (the comparative method). This procedure can distinguish genuinely related words from chance resemblance, and cognates inherited from the proto-language from loanwords.

Language phylogenies obtained by Bayesian phylogenetic methods (Sagart et al. 2019; Zhang et al. 2019; Zhang et al. 2020) ${ }^{2}$ on the basis of cognates in the basic vocabulary provide dates for protolanguages which can be compared with archaeological evidence. We use the dates in Sagart et al. (2019), which is the only one of the three studies that took borrowing from Tibetan and Chinese into account.

Yak Terminologies

Yak-related terminology varies considerably in size and complexity. Languages spoken outside of the natural habitat of domestic and wild yaks (see Supplementary Materials 2) usually lack specific terms for this animal, and with a few exceptions detailed below, employ borrowings from Tibetan (like English yak).

Most of the languages of the southern zone belong to the Sino-Tibetan family, and the relevant terms are indicated in Table $1^{3}$. The phylogenetic relationship between these subgroups is shown in Figure 2, representing the nodes with posterior probability $>90 \%$ in Sagart et al. (2019). The group 'Para-Rgyalrongic' in Table 1 is paraphyletic.

Tibetan also has special names for F2 hybrids, only involving female hybrid yaks, since the males are sterile: उसाख mgal and offspring of female hybrids with male yaks and bulls, respectively. In addition to Tibetan, Rgyalrongic languages also have a distinct term for F2 hybrids: kətó in Situ and rts ${ }^{\text {h }}$ ææætû in Khroskyabs, whose last syllable could be reconstructed to proto-Rgyalrongic.

Some languages have only one word for both males and females, and do not distinguish between yaks and hybrid yaks, whereas other languages have four different terms, in all cases different from those that designate taurine cattle.

Among the languages that have distinct terms for male and female animals, some express it by using feminine or masculine suffixes (for instance, the suffix

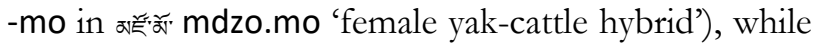
other languages have suppletive forms, i.e., use different roots to designate female and male animals. Amdo Tibetan is reported to have more than 24 terms for yaks depending on sex and age (Tournadre and Suzuki 2021:11.7.1), but these terms are transparently analyzable and therefore recent.

The Tibetan terms have been borrowed by neighboring Sino-Tibetan speakers who lack native terms for yaks, F1 and F2 hybrids. This is the case of Guiqiong in Eastern Tibet, of Kurtoep and other East Bodish languages in Bhutan (Gwendolyn Hyslop, p.c.), of Bokar among Tani languages (the other Tani languages lack terms for yaks altogether, Mark Post, 
Table 1 Terms for domestic yaks in selected Sino-Tibetan languages of the Southern zone.

\begin{tabular}{|c|c|c|c|c|c|}
\hline \multirow[t]{2}{*}{ Subgroup } & \multirow[t]{2}{*}{ Language } & \multicolumn{2}{|c|}{ Yak } & \multicolumn{2}{|c|}{ Yak-Cattle hybrid } \\
\hline & & Male & Female & Male & Female \\
\hline \multirow[t]{3}{*}{ Tibetic } & Old Tibetan & चाज्या gjag & स्बे "bri & कर्द. mdzo & 小店每 mdzo.mo \\
\hline & Lhasa Tibetan & jâ & tşì & tsò & tsòmo \\
\hline & Amdo Tibetan & hjax & ndz̨ə & ndzo & ndzomo \\
\hline Tamangic & Thakali & $545 \mathrm{ja}$ & ${ }^{545}$ pri & & \\
\hline \multirow[t]{6}{*}{ Rgyalrong } & Japhug & qambru & qra & jla & fstor \\
\hline & Zbu & qe $e^{n}$ rú? & $q^{h}$ rí? & Ifé? & $\mathrm{fts}^{\mathrm{h}}$ ós? \\
\hline & Tshobdun & qenbrú? & qrê & jlê & $\mathrm{fts} \hat{~}$ \\
\hline & Situ & kəmbrû & karâ & təjlik̂ & mbə๔ák \\
\hline & Khroskyabs & вbrô & $q^{h} r_{i}$ & çâ & vzóy \\
\hline & Stau & вja & qro & $x \partial$ & zo \\
\hline \multirow{5}{*}{ Para-Rgyalrongic } & Smarskad & mdzô & râ & Zว̆ & zù.mát ${ }^{\#}$ \\
\hline & Ndrapa & $\mathrm{ptş}^{55}$ & $\mathrm{zi}^{55}$ & $a^{33} s k o^{55}$ & $\mathrm{zo}^{55}$ \\
\hline & Rma & z̧bə & вu mic & khşદ & 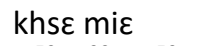 \\
\hline & Muya & ndżõ ${ }^{53}$ & $\mathrm{r}^{33} \mathrm{ma}^{53}$ & ziyə & $z i^{53} z^{33} m a^{53}$ \\
\hline & Pumi & lWé & jwemí & & t6û \\
\hline \multirow[t]{2}{*}{ Naic } & Namuyi & $b u^{53}$ & $\mathrm{bu}^{55} \mathrm{mi}^{53}$ & $z u^{55} \gamma \partial^{31}$ & $\mathrm{zt}^{55} \mathrm{\gamma}^{31} \mathrm{mi}^{53}$ \\
\hline & Naxi & & & bə」 & \\
\hline \multirow[t]{2}{*}{ Ersuic } & Ersu & & & bỵ1 & \\
\hline & Lizu & & & $F_{\text {גæ }}$ & \\
\hline Kiranti & Limbu & & & phunbit & \\
\hline Mishmic & Idu & & & sā pūú & \\
\hline Kho-Bwa & Puroik & & & $c ̧ i^{33}-b e^{d} i^{55 t}$ & \\
\hline Hruso-Miji & Hruso & & & fu bzə & \\
\hline \multirow[t]{2}{*}{ Chinese } & Old Chinese & \multicolumn{2}{|c|}{ 揧 $\mathrm{mæw}<{ }^{*} \mathrm{mr}^{\varsigma} \mathrm{u}$} & & \\
\hline & Mandarin & \multicolumn{2}{|c|}{ 牦牛 máoniú } & 犏牛 piān & \\
\hline
\end{tabular}

"Terms borrowed from Tibetan.

p.c.), and Kho-Bwa languages including Puroik and Duhumbi (Bodt 2020:296).

A specific term for wild yak is found in Tibetic languages (Old Tibetan a borrowed into neighboring languages, including Japhug smbron and Pumi dõ.

Since the yak is known through products from its fur and horns, terms for yak also exist in Sino-Tibetan languages spoken outside of the natural range of the animal. In Yunnan and Burma, languages with native terms for yaks include Jinghpo (wāhpò' 'yak'), Rawang (shv́pè) and some Lolo-Burmese languages such as Lahu ( $\mathrm{nu}^{53} \mathrm{mv}^{33}$ 'yak', nu ${ }^{53} \mathrm{to}^{53}$ 'yak hybrid'), Zaiwa (mau ${ }^{55}$ phjap $^{51}$ no $^{21}$ 'yak', no ${ }^{21}$ phu? ? $^{51}$ 'yak hybrid'), all involving the native words for 'cow' (for instance, the syllable $\mathrm{nu}^{53}$ in Lahu).

The yak-related vocabulary is less rich in nonSino-Tibetan languages, as shown in Table $2^{4}$. Only some Mongolic languages, notably Khalkha, have native terms for yak hybrids; the other languages, including Burushaski and Southern Mongolic languages, have borrowed the term from Tibetic (Nugteren 2011:532).

In addition, Mongghul has innovated a term for 'wild yak' se:nag from an etymon designating bovids or ovids in other Mongolic languages (Nugteren 2011:486).

\section{Attested Semantic Innovations}

Among the language groups discussed in the previous section, only Tibetic, Chinese, Turkic, Mongolic, and Indic have ancient written records. Comparison of the meanings of these words in ancient texts with recent languages offers insight into possible semantic changes. Two cases are detailed below.

First, the terms for male and female hybrid yaks

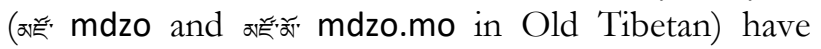
become ndż̀ 'bull' and ndzõ: 'cow' in Cone (by 


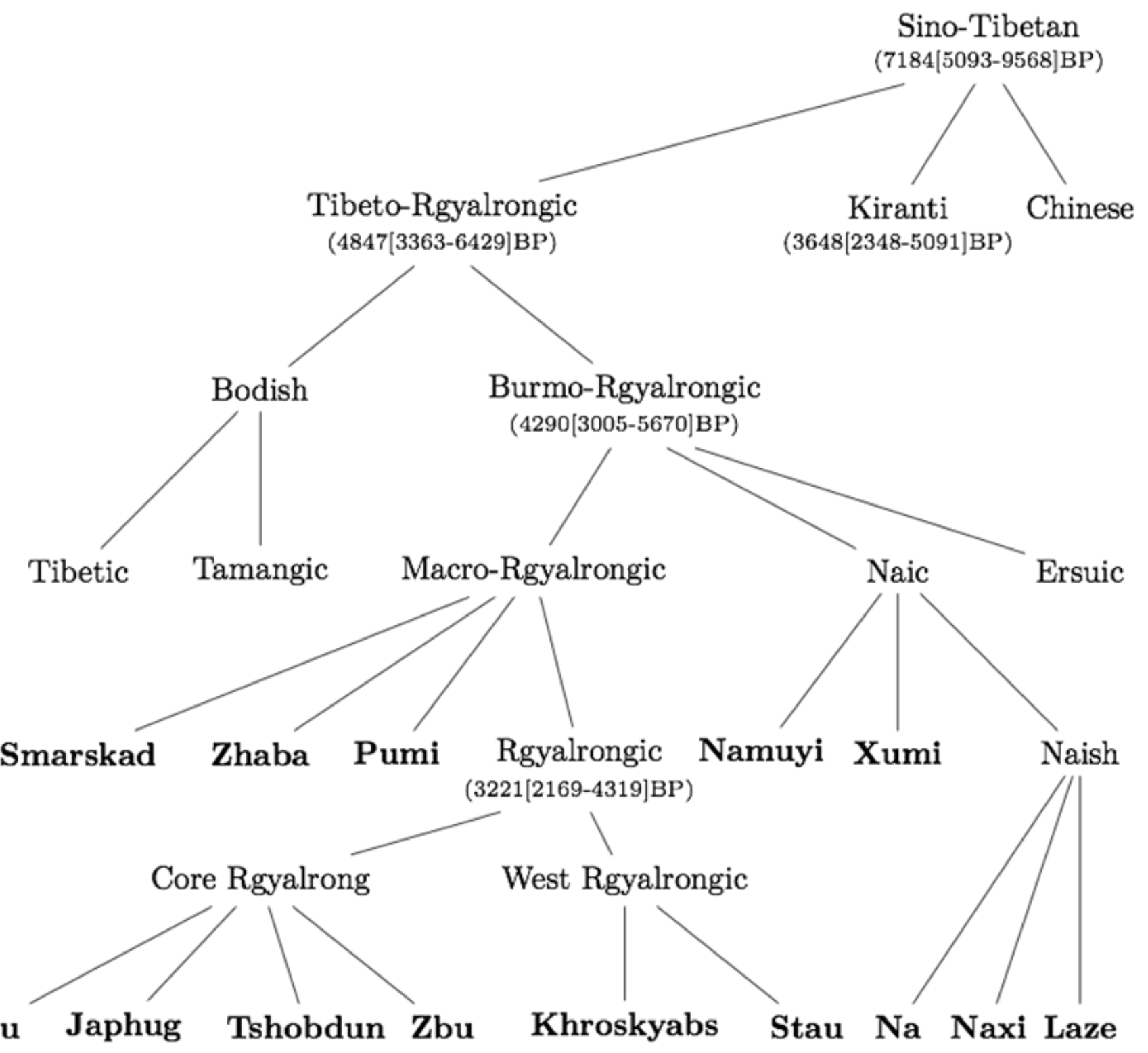

Figure 2 Simplified topology of the Sino-Tibetan phylogenetic tree (terminal nodes in bold). Tree topology and ages inferred are based on the relaxed-clock covarion model, data cited from Sagart et al. (2019).

contrast, the terms for 'yak' have remained stable).

Second, in the Mongolic languages of Gansu and Qinghai (Shironglic), the inherited 'hybrid yak' etymon qayinuy has shifted to 'yak' as in Mongghul xe:nag (Nugteren 2011:532), ousting the etymon sarluy 'yak'. The semantic slot 'hybrid yak' was filled by a loanword from Tibetan zo: mdzo (for instance Mongghul musu), which may have already been borrowed in the common ancestor of Shironglic languages (Nugteren 2011:400).
These two examples show that semantic shifts between 'yak' and 'yak hybrid' are bidirectional.

\section{Etymology and Phylogeny}

In the data presented in 4.1, some languages (for instance, Burushaski, Uighur, Wakhi or Rawang) have isolated terms for 'yak'. Two sets of terms with suppletive gender distinction are reconstructible for Tibetic and Rgyalrongic languages.

In Tibetic, the terms गाराण' gjag 'male yak', 2âे' 'bri

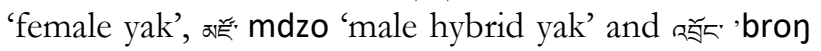


Table 2 Terms for domestic yaks in the non-Sino-Tibetan languages.

\begin{tabular}{|c|c|c|c|c|}
\hline Family & Language & Male Yak & Female yak & Yak hybrid \\
\hline Indo-European & $\begin{array}{l}\text { Sanskrit } \\
\text { Nepali } \\
\text { Wakhi }\end{array}$ & $\begin{array}{l}\text { camara- } \\
\text { cauṃrī } \\
\text { czuuy̆ }\end{array}$ & camarī- & \\
\hline Buruskaski & $\begin{array}{l}\text { Hunza } \\
\text { Yasin }\end{array}$ & $\begin{array}{l}\text { bépay. } \\
\text { bépa }\end{array}$ & sum bépa & zó $^{\#}$ \\
\hline Turkic & $\begin{array}{l}\text { Old Uighur } \\
\text { Tuva }\end{array}$ & $\begin{array}{l}\text { kotoz } \\
\text { sarlikk }\end{array}$ & & hainak sarlik \\
\hline Mongolic & $\begin{array}{l}\text { Cl. Mongolian } \\
\text { Khalkha } \\
\text { Mongghul } \\
\text { Yugur } \\
\text { Bonan }\end{array}$ & $\begin{array}{l}\text { sarluy } \\
\text { сарлаг } \\
\text { хе:nag் } \\
\text { xainag் } \\
\text { warxan }\end{array}$ & $n d z \partial^{\#}$ & $\begin{array}{l}\text { qауinuy } \\
\text { хайнаг } \\
\text { musu\# } \\
\text { omsə\# } \\
\text { өmsə\# }\end{array}$ \\
\hline
\end{tabular}

"Terms borrowed from Tibetan.

'wild yak' are attested in documents from the Tibetan empire (Laws of hunting, PT 1071, $8^{\text {th }}$ century CE), and have remained stable in most Tibetic languages (except isolated cases like Cone, see section 4.2). These etyma are not based on the words for taurine cattle (파. glan 'bull', অ' ba 'cow'), and have been largely borrowed, either partially or as a full set, into neighboring languages (Mongolic, Burushaski, Guiqiong, Kho-Bwa). Genuine cognates of the Tibetan etyma for domestic yak are only found in Tamangic (*Bhja: 'male yak', ${ }^{* B}$ prit 'female yak'; Mazaudon 1994), the closest relatives of Tibetic (Figure 2). The term a a.s' 'bron 'wild yak', on the other hand, has many extra-Tibetic cognates, discussed below.

The Tibetic-Tamangic etymon for 'female yak' itself is the probable source of the Sanskrit word camarī- 'female yak' and its reflexes in modern Indic languages (such as Nepali caumrī 'yak'), through a series of complex sound changes (Jacques 2016). This etymon has been also borrowed into Kho-Bwa languages as a general term for the animal, early enough to display the same sound correspondences as the noun 'name' (illustrated in Lieberherr and Bodt 2017).

Unlike Tibetic languages, whose common ancestor is attested as a written language, protoRgyalrongic is not an attested language, and can only be reconstructed by using the comparative method. The only ancient Rgyalrongic language, Tangut, only has one term for 'yak's, possibly a consequence of the migration of its speakers from North-West Sichuan into Ningxia and Shaanxi (Lai et al. 2020).
All Rgyalrongic languages other than Tangut have suppletive terms (Table 3), and present the phonetic correspondences expected from cognates: at least 'male yak', 'female yak' and 'female yak-cattle hybrid' are reconstructible to proto-Rgyalrongic.

Other domesticated mammals whose names are reconstructible to proto-Rgyalrongic include taurine cattle (two terms, see Table 3), sheep, goat, and pigs (Sagart et al. 2019). In addition, the reconstructibility of the verb 'to herd' Japhug lyy, Situ lék, Khroskyabs lây) confirms that the common ancestors of Rgyalrong-speaking peoples were familiar with cattle herding.

Outside of Rgyalrongic, the etymon for 'female yak' is attested with certainty only in Ersuic *rA 'yak' (Yu, 2012, 73, 84).

By contrast, the etymon for 'male yak' (Zbu qen brú?, Khroskyabs ubrô) has cognates outside of this subgroup. It seems to correspond to the word for 'male yak' in some Para-Rgyalrongic languages (notably Muya ndz $\tilde{0}^{53}$ ), though this is difficult to prove in the absence of in-depth study of the historical phonology of these languages. It is also cognate to the unique etymon for 'yak' in Naish (Naxi bə」, Na bvג, Laze bv1, Proto-Naish *bru; Jacques and Michaud 2011), to Xumi (formerly known as Shixing) ${ }^{H}$ bõ (Chirkova 2009:17), Ersuic *bu 'male yak' (Yu 2012:100), and to Tibetan a a

In addition, Burmese pron 'gaur' (Bos gaurus) is a likely cognate of this etymon. Given the fact that this etymon means 'yak' in both Tibetic and Rgyalrongic on the one hand, and that Rgyalrongic and Burmese 
Table 3 Cognate sets in Rgyalrongic languages.

\begin{tabular}{|c|c|c|c|c|c|c|}
\hline & \multicolumn{2}{|c|}{ Cattle } & \multicolumn{2}{|c|}{ Yak } & \multicolumn{2}{|c|}{ Yak-Cattle hybrid } \\
\hline & Male & Female & Male & Female & Male & Female \\
\hline Japhug & mbala & nuna & qambru & qra & jla & ftsor \\
\hline Zbu & nbolé? & nwé? & $q e^{n} b r u ́ ?$ & $q^{h}$ rí? & lfé? & $\mathrm{fts}^{\mathrm{h}}$ ót? \\
\hline Tshobdun & nbolé? & nê & $q e^{n} b r u ́ ?$ & qrê & jlê & ftsô \\
\hline Situ & balik̂ & nəクiर̂ & kəmbrû & karâ & təjlik̂ & \\
\hline Khroskyabs & bəlé & nî & вbrô & $q^{h}$ ríp & & vzóy \\
\hline Stau & & & & qrə & & zo \\
\hline
\end{tabular}

are closer to each other than either it to Tibetan on the other hand (since they belong to the BurmoRgyalrongic branch, a clade supported by all phylogenetic studies, Zhang et al. 2019; Sagart et al. 2019; Zhang et al. 2020), Burmese has undergone a semantic shift from 'yak' to 'gaur' than the other way round, and the meaning 'yak' can be reconstructed back to the common ancestor of Tibetic and Rgyalrongic.

The Old Chinese term mæw 訤 (first attested in the text Guoyu, dating from the Warring states period, 475-221 BCE) is reconstructed as ${ }^{*} \mathrm{mr}^{\varsigma} \mathrm{u}$ (in Baxter and Sagart's 2014 system). This reconstructed form is compatible with the Rgyalrongic-Tibetic etymon, and could reflect a borrowing from a Rgyalrongic language after the loss of final ${ }^{*}-\eta$.

Two conclusions relevant to the question of yak domestication can be drawn from the evidence presented above.

First, one term for 'yak' is reconstructible to proto-Tibeto-Rgyalrongic (4847[3363-6429] BP; Sagart et al. 2019) ${ }^{6}$, without distinction between wild and domesticated animals, and between yaks and yakcattle hybrids. This fact indicates familiarity with the animal but does not necessarily imply domestication.

Second, at least three etyma for male and female yak and F1 hybrids distinct from those of cattle, are reconstructible in proto-Rgyalrongic (3221 [21694319] BP; Sagart et al. 2019) ${ }^{7}$. Since all Rgyalrongic languages (except Tangut, whose migration is documented in historical records) are spoken in the Rngaba and Dkarmdzes districts of western Sichuan (see the map in Figure 1), the reconstructibility of these etyma entails that cross-breeding between taurine cattle and yak was already well-established in this part of the Eastern Tibetan Plateau before the split of the Rgyalrongic subgroup three millennia ago.

\section{Discussion}

Our linguistic reconstruction indicates that domestication of yaks took place sometime after the split of Tibeto-Rgyalrongic (4847[3363-6429] BP), but before that of Rgyalrongic (3221 [2169-4319] $\mathrm{BP})$, and that the domestication process possibly took place independently in two places, among the ancestors of Rgyalrongic and Tibetic, respectively.

The timing of yak domestication according to linguistic reconstructions appears to correspond to a period of time that postdates the introduction of taurine cattle to the Northwestern China and the margins of the Tibetan Plateau, as shown in Figure 3. Given the fact that the name for F1 hybrids is reconstructible to proto-Rgyalrongic, it is possible that the introduction of taurine cattle and contact with people who herded cattle may have inspired protoRgyalrongic speaking peoples to begin to herd, pen and carry out the more intensive type of management of this animal that led to its domestication. Hybridization of taurine cattle with yaks may have further conferred traits that further facilitated human management such as higher quality milk production, lower aggressivity and increased tolerance to human presence.

This hybridization process may have resulted from human intervention but could also have taken place between wild yaks and feral cattle, the resulting offspring being more amenable to human management.

Linguistic evidence further suggests that two yak domestication events may have taken place, one on the western Tibetan Plateau, associated with the ancestors of Tibetan speakers, and one on the eastern Plateau, associated with proto-Rgyalrongic speakers. 


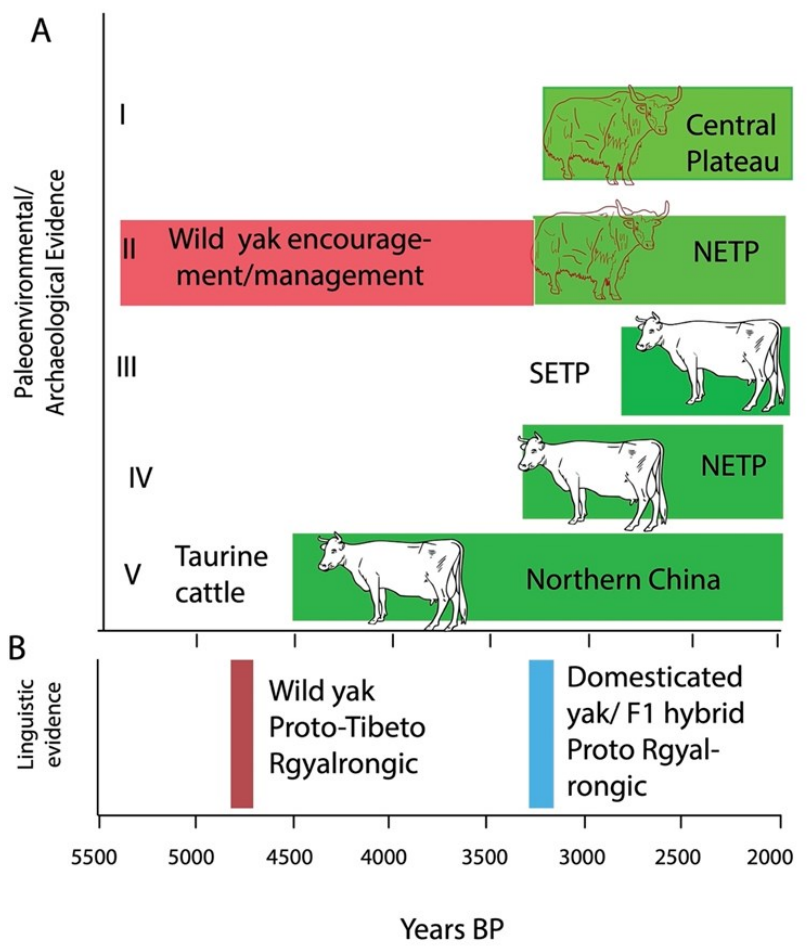

Figure 3 Comparison of linguistic and archaeological evidence for yak domestication. Panel $A$ indicates the archaeological and paleoenvironmental evidence for yak domestication and management. In lines I-II, the area in red indicates the period during which wild yak population growth may have been encouraged through anthropogenic burning. Areas in green indicate potentially domesticated yak. In lines III-V, areas in green indicate the introduction of taurine cattle. Panel B shows the hypothesized date at which terms for wild and domesticated yak are present.

This is unsurprising as Kham and Amdo contain some of the richest biomes for wild forage used by yaks and wild animals would likely have concentrated in this area. The large numbers of lower altitude river valleys which cross-cut this area also likely brought yaks into contact with farmers who had begun to fodder taurine cattle and other domesticates like sheep.

As this paper details, we are only beginning to learn about how humans first began to manage and eventually domesticate yaks. Future archaeological and genetic research will be important in testing the time frame that the linguistic evidence we presented in this paper suggests for this animal's domestication. Future aDNA work could help resolve the timing of when hybridization between yak and taurine cattle first took place and the location of where such hybrids were first developed. In order to carry out this work, we require more systematic sampling of animal bones to take place at excavations on the Plateau. Since the male yak-cattle hybrids are sterile (Niayale et al. 2021), and only the female can have offspring, we would expect absence from introgression in the $\mathrm{Y}$ chromosome (Medugorac et al. 2017). For this reason, aDNA sampling would need to be based on large samples to identify female individuals on which sampling could be carried out. Future zooarchaeological work could also help identify how humans managed the yaks that they began to domesticate. Do kill off profiles show strategies aimed primarily at meat or milk extraction (Vigne and Helmer 2007)? We hope that future research in this area will help resolve some of these issues.

\section{Notes}

${ }^{1}$ In addition, yaks have been more recently introduced in other areas, including Yakutia and Ossetia, which are not represented here. This map is based on different sources depending on the countries: for Mongolia, the official statistics on yak population (http://www.1212.mn/tables.aspx?

TBL_ID=DT_NSO_1001_052V2) were consulted, for China we used an important number of sources to ascertain the existence of yaks in various districts, cited in the supplementary document, and was used for other countries.

${ }^{2}$ The applicability of phylogenetic methods in historical linguistics is still controversial. However, while these three articles were based on three independent datasets, their results present a high degree of congruence.

${ }^{3}$ For editorial reasons, the complete dataset and the references cannot be shown here and are included in a supplementary document.

${ }^{4}$ This table does not include all Indo-Aryan and Mongolic languages spoken in yak-herding areas. The relevant data on Mongolic languages can be found in (Nugteren 2011:400, 532).

${ }^{5}$ Tangut $1195 \mathrm{k}^{\mathrm{h}} \mathrm{ie}$ 'yak' is cognate with the word meaning 'female yak' in other languages.

${ }^{6}$ This date reflects the covarion relaxed clock analysis; Sagart et al. (2019) obtained 5816 [5007-6715] BP and 5684 [4916-6449] BP in the Dollo and Covarion strict clock analyses for this branch, respectively. Other phylogenetics studies (Zhang et al. 2019; 2020) find less support for a Tibeto-Rgyalrongic branch. The 
common ancestor of Rgyalrongic and Tibetic is thus slightly more ancient in their results.

${ }^{7}$ With other methods the dates obtained were 4026 [3430-4640] BP for Covarion strict clock and 3540 [3540-4063] for Dollo.

\section{References Cited}

Aldenderfer, M., and J. T. Eng. 2016. Death and Burial among Two Ancient High-Altitude Communities of Nepal. In Companion to South Asia in the Past, edited by G. Robbins Schug and S. R. Walimbe, pp. 374-397. Wiley-Blackwell, London. DOI:10.1002/9781119055280.ch24.

Bailey, J. F., B. Healy, J. Han, L. Sherchand, S. L. Pradhan, T. Tsendsuren, J. M. Foggin, C. Gaillard, D. Steane, and D. G. Zakharov, I. Bradley. 2002. Genetic Variation of Mitochondrial DNA Within Domestic Yak Populations. In Proceedings of the Third International Congress on Yak, pp. 181-189, September 4-9, 2000, Lhasa, China

Baxter, W. H., and L. Sagart. 2014. Old Chinese: A New Reconstruction. Oxford University Press, Oxford.

Bodt, T. A. 2020. Grammar of Dubumbi (Chugba). Brill, Leiden.

Brown, C. H., C. R. Clement, P. Epps, E. Luedeling, and S. Wichmann. 2013. The Paleobiolinguistics of Chili Pepper (Capsicum spp.). Ethnobiology Letters 4:111. DOI:10.14237/ebl.4.2013.2.

Brunson, K., L. Ren, X. Zhao, X. Dong, H. Wang, J. Zhou, and R. Flad. 2020. Zooarchaeology, Ancient mtDNA, and Radiocarbon Dating Provide New Evidence for the Emergence of Domestic Cattle and Caprines in the Tao River Valley of Gansu Province, Northwest China. Journal of Archaeological Science: Reports 31:102262. DOI:10.1016/ j.jasrep.2020.102262.

Cai, D., Y. Sun, Z. Tang, S. Hu, W. Li, X. Zhao, H. Xiang, and H. Zhou. 2014. The Origins of Chinese Domestic Cattle as Revealed by Ancient DNA Analysis. Journal of Archaeological Science 41:423-434. DOI:10.1016/j.jas.2013.09.003.

Chen, N., Y. Cai, Q. Chen, R. Li, K. Wang, Y. Huang, S. Hu, S. Huang, H. Zhang, Z. Zheng, W. Song, Z. Ma, Y. Ma, R. Dang, Z. Zhang, L. Xu, Y. Jia, S. Liu, X. Yue, W. Deng, X. Zhang, Z. Sun, X. Lan, J. Han, H. Chen, D. G. Bradley, Y. Jiang, and C. Lei. 2018. Whole-Genome Resequencing Reveals World -Wide Ancestry and Adaptive Introgression Events of Domesticated Cattle in East Asia. Nature
Communications 9:2337. DOI:10.1038/s41467-01804737-0.

Chirkova, K. 2009. Shixing, a Sino-Tibetan Language of South-West China: A Grammatical Sketch with Two Appended Texts. Linguistics of the Tibeto-Burman Area 32:1-90.

Dong, G., L. Ren, X. Jia, X. Liu, S. Dong, H. Li, Z. Wang, Y. Xiao, and F. Chen. 2016. Chronology and Subsistence Strategy of Nuomuhong Culture in the Tibetan Plateau. Quaternary International 426:42-49. DOI:10.1016/j.quaint.2016.02.031.

Flad, R. K., J. Yuan, and S. Li. 2007. Zooarchaeological Evidence for Animal Domestication in Northwest China. In Late Quaternary Climate Change and Human Adaptation in Arid China, edited by D. B. Madsen, F. H. Chen, and G. Xing, pp. 167-204. Elsevier, Amsterdam. DOI:10.1016/S1571-0866 (07)09012-4.

Guo, S., P. Savolainen, J. Su, Q. Zhang, D. Qi, J. Zhou, Y. Zhong, X. Zhao, and J. Liu. 2006. Origin of Mitochondrial DNA Diversity of Domestic Yaks. BMC Evolutionary Biology 6:73. DOI:10.1186/1471-2148-6-73.

Hock, H. H. 1991. Principles of Historical Linguistics. Mouton de Gruyter, Berlin.

Huang, X., J. Zhang, M. Storozum, S. Liu, J. L. Gill, L. Xiang, X. Ren, J. Wang, M. Qiang, F. Chen, and E. C. Grimm. 2020. Long-Term Herbivore Population Dynamics in the Northeastern QinghaiTibetan Plateau and its Implications for Early Human Impacts. Review of Palaeobotany and Palynology 275:104171. DOI:10.1016/j.revpalbo.2020.104171.

Hyslop, G. 2013. On the Internal Phylogeny of East Bodish. In North East Indian linguistics 5, edited by Gwendolyn Hyslop, Stephen Morey, and Mark W. Post, pp.91-112. Cambridge University Press India, New Delhi.

Jacques, G. 2016. Sanskrit Camara- 'Yak' et Tibétain Nbri 'Yak Femelle'. *Wékwos 2:87-90.

Jacques, G., and A. Michaud. 2011. Approaching the Historical Phonology of Three Highly Eroded SinoTibetan Languages: Naxi, $\mathrm{Na}$ and Laze. Diachronica 28:468-498. DOI:10.1075/dia.28.4.02jac.

Joshi, S., L. Shrestha, N. Bisht, Ning Wu, M. Ismail, T. Dorji, G. Dangol, and R. Long. 2020. Ethnic and Cultural Diversity Amongst Yak Herding Communities in the Asian Highlands. Sustainability 12(3):957. DOI:10.3390/su12030957. 
Kaoguxi, Sichuan Daxue, Jiuzhaigou Fengjing Mingxing Guanliju, University of Washington Department of Anthropology, and Abazhou Wenwu Guanlisuo. 2017. 九寨沟景区历史文化资 源考察研究报告 Jiu $\square$ zhàigōu ji $\square$ ngqū lìshi $\square$ wénhuà zịyuán ka $\square$ ochá yánjiū bàogào [Research Report on the History, Culture and Natural Resources of the Jiuzhaigou National Park]. Bashu Shushe, Chengdu, China.

Lai, Y., X. Gong, J. P. Gates, and G. Jacques. 2020. Tangut as a West Gyalrongic Language. Folia Linguistica Historica 41:171-203. DOI:10.1515/flih2020-0006.

Lieberherr, I., and T. A. Bodt. 2017. Sub-grouping Kho-Bwa Based on Shared Core Vocabulary. Himalayan Linguistics 16:26-63.

Lu, P., K. Brunson, J. Yuan, and Z. Li. 2017. Zooarchaeological and Genetic Evidence for the Origins of Domestic Cattle in Ancient China. Asian Perspectives 56:92-120. DOI:10.1353/asi.2017.0003.

Mazaudon, M. 1994. Problèmes de Comparatisme et de Reconstruction dans Quelques Langues de la Famille Tibétobirmane. Thèse d'Etat, Université de la Sorbonne Nouvelle, Paris.

Medugorac, I., A. Graf, C. Grohs, S. Rothammer, Y. Zagdsuren, E. Gladyr, N. Zinovieva, J. Barbieri, D. Seichter, I. Russ, A. Eggen, G. Hellenthal, G. Brem, H. Blum, S. Krebs, and A. Capitan. 2017. WholeGenome Analysis of Introgressive Hybridization and Characterization of the Bovine Legacy of Mongolian Yaks. Nature Genetics 49:470-475. DOI:10.1038/ng.3775.

Meyer, M. C., C. Hoffman, A. M. D. Gemmel, E. Haslinger, H. Hausler, and D. Wangda. 2009. Holocene Glacier Fluctuations and Migration of Neolithic Yak Pastoralists into the High Valleys of Northwest Bhutan. Quaternary Science Review 28:1217 -1237. DOI:10.1016/j.quascirev. 2008.12.025.

Miehe, G., S. Miehe, J. Böhner, K. Kaiser, I. Hensen, D. Madsen, J. Liu, and L. Opgenoorth. 2014. How Old is the Human Footprint in the World's Largest Alpine Ecosystem? A Review of Multiproxy Records from the Tibetan Plateau from the Ecologists' Viewpoint. Quaternary Science Reviews 86:190-209. DOI:10.1016/j.quascirev.2013.12.004.

Miehe, G., S. Miehe, K. Kaiser, C. Reudenbach, L. Behrendes, L. Duo, and F. Schlütz. 2009. How Old is Pastoralism in Tibet? An Ecological Approach to the Making of a Tibetan Landscape. Palaeogeography, Palaeoclimatology, Palaeoecology 276:130-147. DOI:/10.1016/j.palaeo.2009.03.005.

Niayale, R., Y. Cui, and F. Adzitey. 2021. Male Hybrid Sterility in the Cattle-Yak and Other Bovines: A Review. Biology of Reproduction 104:495-507. DOI:10.1093/biolre/ioaa207.

Nugteren, H. 2011. Mongolic Phonology and the QinghaiGansu Languages. Doctoral Dissertation, Leiden University, Leiden, Netherlands. Available at: https://www.lotpublications.nl/mongolicphonology-and-the-qinghai-gansu-languagesmongolic-phonology-and-the-qinghai-gansulanguages. Accessed on July 28, 2021.

Qi, X., H. J., G. Wang, J. E. O. Rege, and O. Hanotte. 2010. Assessment of Cattle Genetic Introgression into Domestic Yak Populations Using Mitochondrial and Microsatellite DNA Markers. Animal Genetics 41:242-252. DOI:10.1111/j.13652052.2009.01989.x.

Qi, X., J. Han, R. Blench, J. E. O. Rege, and O. Hanotte. 2008. Understanding Yak Pastoralism in Central Asian Highlands Mitochondrial DNA Evidence for Origin, Domestication and Dispersal of Domestic Yak. In Past Human Migrations in East Asia: Matching Archaeology, Linguistics and Genetics, edited by Alicia Sanchez-Mazas, Roger Blench, Malcolm Ross, Ilia Peiros, and Mary Lin, pp. 427442. Routledge, London.

Qinghai Sheng Wenwu Guanli Huiyuanhui, and Zhongguo Shehui Kexue Yuan Kaogu Yanjiusuo Qinghai Dui. 1963. 青海都兰县诺木洪搭里他里 哈遗址调查与试掘 Qīnghăi Dūlánxiàn Nuòmùhóng dālľtālľhā yízhǐ diàochá yǔ shìjué [A Report on the Survey and Excavations at the Nuomuhong Culture Site of Dalitaliha in Dulan County, Qinghai]. Kaogu Xuebao 1:7-41.

Qiu, Q., L. Wang, K. Wang, Y. Yang, T. Ma, Z. Wang, X. Zhang, Z. Ni, F. Hou, R. Long, R. Abbott, J. Lenstra, and J. Liu. 2015. Yak WholeGenome Resequencing Reveals Domestication Signatures and Prehistoric Population Expansions. Nature Communications 6:10283. DOI:10.1038/ ncomms10283.

Qiu, Q., G. Zhang, T. Ma, W. Qian, J. Wang, Z. Ye, C. Cao, Q. Hu, J. Kim, D. M. Larkin, L. Auvil, B. Capitanu, J. Ma, H. A. Lewin, X. Qian, Y. Lang, R. Zhou, L. Wang, K. Wang, J. Xia, S. Liao, S. Pan, X. 
Lu, H. Hou, Y. Wang, X. Zang, Y. Yin, H. Ma, J. Zhang, Z. Wang, Y. Zhang, D. Zhang, T. Yonezawa, M. Hasegawa, Y. Zhong, W. Liu, Y. Zhang, Z. Huang, S. Zhang, R. Long, H. Yang, J. Wang, J. A. Lenstra, D. N. Cooper, Y. Wu, J. Wang, P. Shi, J. Wang, and J. Liu. 2012. The Yak Genome and Adaptation to Life at High Altitude. Nature Genetics 44:946-949. DOI:10.1038/ng.2343.

Rhode, D., D. B. Madsen, P. J. Brantingham, and T. Dargye. 2007. Yaks, Yak Dung, and Prehistoric Human Habitation of the Tibetan Plateau. Developments in Quaternary Sciences 9:205-224. DOI:10.1016/S1571-0866(07)09013-6.

Sagart, L., G. Jacques, Y. Lai, R. J. Ryder, V. Thouzeau, S. J. Greenhill, and J.-M. List. 2019. Dated Language Phylogenies Shed Light on the Ancestry of Sino-Tibetan. Proceedings of the National Academy of Sciences 116:10317-10322. DOI:10.1073/ pnas.1817972116.

Schlütz, F., and F. Lehmkuhl. 2009. Holocene Climatic Change and the Nomadic Anthropocene in Eastern Tibet: Palynological and Geomorphological Results from the Nianbaoyeze Mountains. Quaternary Science Reviews 28:1449-1471. DOI:10.1016/j.quascirev.2009.01.009.

Sun, J. T.-S. 2000. Stem Alternations in Puxi Verb Inflection: Toward Validating the Rgyalrongic Subgroup in Qiangic. Language and Linguistics 1:211232.
Tournadre, N., and H. Suzuki. 2021. The Tibetic Languages, an Introduction to the Family of Languages Derived from Old Tibetan. Lacito Publications, Paris.

Vigne, J. D., and D. Helmer. 2007. Was Milk a "Secondary Product" in the Old World Neolithisation Process? Its Role in the Domestication of Cattle, Sheep and Goats. Anthropozoologica 42:9-40.

Yu, D. 2012. Proto-Ersuic. Doctoral Dissertation, Graduate Division, University of California, Berkeley, CA. Available at: https:// linguistics.berkeley.edu/ dom/proto-ersuic.pdf. Accessed on July 29, 2021.

Zhang, H., T. Ji, M. Pagel, and R. Mace. 2020. Dated Phylogeny Suggests Early Neolithic Origin of Sinotibetan Languages. Scientific Reports 10:20792. DOI:10.1038/s41598-020-77404-4.

Zhang, M., S. Yan, W. Pan, and L. Jin. 2019. Phylogenetic Evidence for Sino-Tibetan Origin in Northern China in the Late Neolithic. Nature 569:112-115. DOI:10.1038/s41586-019-1153-z.

Zhongguo Shehui Kexueyuan Kaogu Yanjiusuo. 1999. 拉萨曲贡 Làsà qügòng [The Qugong culture of Lhasa]. Zhongguo dabaikequanshu chubanshe, Beijing. 